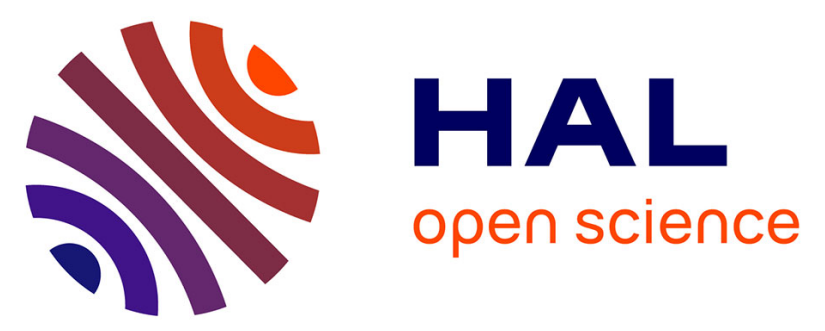

\title{
Molecular evidence for the coexistence of two sibling species in Pylaiella littoralis (Ectocarpales, Phaeophyceae) along the Brittany coast
}

Alexandre Geoffroy, Stéphane Mauger, Aurélien de Jode, Line Le Gall, Christophe Destombe

\section{To cite this version:}

Alexandre Geoffroy, Stéphane Mauger, Aurélien de Jode, Line Le Gall, Christophe Destombe. Molecular evidence for the coexistence of two sibling species in Pylaiella littoralis (Ectocarpales, Phaeophyceae) along the Brittany coast. Journal of Phycology, 2015, 51 (3), pp.480-489 10.1111/jpy.12291 . hal-01147191

\section{HAL Id: hal-01147191 \\ https://hal.sorbonne-universite.fr/hal-01147191}

Submitted on 29 Apr 2015

HAL is a multi-disciplinary open access archive for the deposit and dissemination of scientific research documents, whether they are published or not. The documents may come from teaching and research institutions in France or abroad, or from public or private research centers.
L'archive ouverte pluridisciplinaire HAL, est destinée au dépôt et à la diffusion de documents scientifiques de niveau recherche, publiés ou non, émanant des établissements d'enseignement et de recherche français ou étrangers, des laboratoires publics ou privés. 
Molecular evidence for the coexistence of two sibling species in Pylaiella littoralis

(Ectocarpales, Phaeophyceae) along the Brittany coast ${ }^{1}$

\begin{abstract}
Alexandre Geoffroy
Sorbonne Universités, UPMC Université Paris 06, UMI 3614 Evolutionary Biology and Ecology of Algae, Station Biologique de Roscoff, CS 90074, 29688 Roscoff, France CNRS, UMI 3614 Evolutionary Biology and Ecology of Algae, Station Biologique de Roscoff, 29688 Roscoff, France
\end{abstract}

Stéphane Mauger

Sorbonne Universités, UPMC Université Paris 06, UMI 3614 Evolutionary Biology and Ecology of Algae, Station Biologique de Roscoff, CS 90074, 29688 Roscoff, France CNRS, UMI 3614 Evolutionary Biology and Ecology of Algae, Station Biologique de Roscoff, 29688 Roscoff, France

Aurélien de Jode

Sorbonne Universités, UPMC Université Paris 06, UMI 3614 Evolutionary Biology and Ecology of Algae, Station Biologique de Roscoff, CS 90074, 29688 Roscoff, France CNRS, UMI 3614 Evolutionary Biology and Ecology of Algae, Station Biologique de Roscoff, 29688 Roscoff, France 


\title{
Line Le Gall
}

Muséum National d'Histoire Naturelle, Institut de Systématique, Evolution, Biodiversité, UMR 7205 CNRS-EPHE-MNHN-UPMC, Equipe Exploration, Espèces, Evolution, case postale $\mathrm{N}^{\circ} 39,57$ rue Cuvier, 75231 Cedex 05 Paris, France

\author{
Christophe Destombe ${ }^{2}$ \\ Sorbonne Universités, UPMC Université Paris 06, UMI 3614 Evolutionary Biology and \\ Ecology of Algae, Station Biologique de Roscoff, CS 90074, 29688 Roscoff, France \\ CNRS, UMI 3614 Evolutionary Biology and Ecology of Algae, Station Biologique de \\ Roscoff, 29688 Roscoff, France \\ ${ }^{2}$ corresponding author Email: christophe.destombe@ sb-roscoff.fr \\ Phone: +33 (0)2 98292320 \\ ${ }^{1}$ date of submission and acceptance
}

Sibling species in Pylaiella littoralis

Editorial Responsibility: O. De Clerck (Associate Editor)

\begin{abstract}
The great phenotypic variability and the lack of diagnostic characters in the genus Pylaiella render the systematic study of this genus problematic. In the present study, we investigated the diversity of Pylaiella littoralis (Linnaeus) Kjellman along the Brittany (France) coast using a DNA barcoding multilocus approach with mitochondrial (cox1, nad1 and atp9) and chloroplastic ( $r b c \mathrm{~L}$ and $a t p \mathrm{~B})$ markers associated with a population genetics approach using 10 microsatellite markers. In addition, spatio-temporal sampling was conducted along the Brittany coast. We sampled 140 individuals from four sites located between Saint-Malo and
\end{abstract}


Concarneau $(380 \mathrm{~km})$ from April to October. Mitochondrial sequence data revealed the occurrence of two sibling species, with a minimum of $2.4 \%$ divergence between them. Microsatellite genotypic data congruently revealed two well-supported clusters matching the two mitochondrial clades of Pylaiella. Although gene flow is limited between species, occurrence of genetic admixtures in some populations suggested that reproductive isolation is not complete. Our study highlighted the complementarity of barcoding and population genetics approaches to shed light on the evolutionary processes that lead to speciation.

Keywords: gene flow, microsatellite, multilocus barcode, Pylaiella littoralis, sibling species.

List of abbreviations

nt, nucleotide

PCA, principal component analysis

FCA, factorial correspondence analysis

cox 1 , cytochrome c oxidase subunit I

$r b c \mathrm{~L}$, ribulose-1,5-biphosphate carboxylase oxygenase large subunits

nad1, NADH dehydrogenase subunit 1

atp9, ATP synthase subunit 9

atp B, ATPase beta subunit

\section{INTRODUCTION}

Most species descriptions in brown algal groups follow the morphological species concept and the delimitation of species is therefore essentially based on discontinuities in morphological characters (Mayden 1997). However, due to phenotypic plasticity and the lack of diagnostic characters in some groups, species delimitation using conventional 
methods is often problematic and has led to erroneous taxonomic assignments (Tellier et al. 2009, Tronholm et al. 2010). Analyses of molecular data have become the closest proxy of species delimitation (for review, Leliaert et al. 2014). The combination of phylogenetic and population genetics approaches can help determine algal diversity and study boundaries between closely related species. As a phylogenetic approach, DNA barcoding — based on discontinuity in sequence variation as diagnostic character - has proven to be an effective tool for delineating species (Sites and Marshall 2003) and has been successfully applied in algae to aggregate individuals into different closely related species (Leliaert et al. 2014). The population genetic approach has been used in brown algae to detect gene flow discontinuity among taxa (Tellier et al. 2011) and to identify hybridization or introgression events (Engel et al. 2005). Population genetic data acquired from microsatellite loci are extremely useful to estimate the extent of gene flow between closely related species.

The brown algal genus Pylaiella includes species characterized by a filamentous structure with various branching patterns. As in most algal groups, systematics in Pylaiella has been centered on morphological species concept. However, Pylaiella species are known for their disconcerting phenotypic plasticity and their lack of diagnostic characters, making species delimitation very problematic (Fritch 1952, Bolton 1979a). More than 90 specific and infraspecific names have been reported for this genus, of which only seven are currently accepted taxonomically (Guiry and Guiry 2014). Pylaiella littoralis (Linnaeus) Kjellman is the most common accepted species and has been reported worldwide in the littoral zones of cold and cold temperate coasts of both hemispheres (Müller and Stache 1989, Silva et al. 1999). More than 50 forms or varieties have been described on the basis of morphology, habitat and seasonal distribution characteristics (Guiry and Guiry 2014). A plethora of authors have suggested that these various forms and varieties can possibly be attributed to 
phenotypic plasticity (i.e., Knight 1923, Newton 1931, Russell 1963, 1967, Bolton 1979b, Müller and Stache 1989). Therefore, no clear consensus has ever been adopted on species delimitation within Pylaiella (Siemer and Pedersen 1995). Molecular tools appear as a useful alternative to morphological observation for clarifying the systematics of the genus Pylaiella.

Although various species, such as Pylaiella anglica Ruprecht and Pylaiella aquitanica Ruprecht, have been reported in England and in south-western France, respectively (Ruprecht 1850), Feldmann (1954), and most authors after him, recognized only P. littoralis at the species level in Brittany, France. In this region, the species is found both on rocky substrates and as an epiphyte of perennial seaweed species (Feldmann 1954). In the northern Baltic Sea, two different seasonal cohorts have been observed, one characterized by rapid growth in early spring with a maximum cover at the beginning of May-June followed by degradation and detachment of filaments and one with a growth period in SeptemberOctober (Kiirikki and Lehvo 1997). Kornmann and Sahling (1977) reported two different species in Helgoland-Northern Sea (P. littoralis and Pylaiella sp.). These authors observed that $P$. littoralis is found throughout the year whereas the second species (later identified as Pylaiella macrocarpa, Kornmann 1990), is observed only in spring.

The aims of the present study were to assess the diversity and its spatio-temporal pattern among populations of $P$. littoralis in Brittany. Toward these objectives, we first used a combination of five molecular markers characterized by different mutation rates and different effective sizes: the mitochondrial genes $\operatorname{cox} 1, \operatorname{nad} 1$ and $\operatorname{atp} 9$, and the two chloroplastic genes $r b c \mathrm{~L}$ and $a t p \mathrm{~B}$ (Silberfeld et al. 2010). In addition to the multilocus approach, we used a population genetics approach based on 10 microsatellite markers to assess gene flow between populations. Mitochondrial sequences combined with the 
population genetics approach revealed the occurrence of two sibling species in Brittany under the name of $P$. littoralis.

\section{MATERIALS AND METHODS}

\section{Sampling}

In total, 140 specimens of Pylaiella littoralis were sampled at four different localities (16-62 specimens per site) along the coast of Brittany, France (Fig. 1), from Dinard to Concarneau (about $380 \mathrm{~km}$ coastline). Sampling was conducted from April to October (Table 1) to compare spring and autumn samples. In the laboratory, a fragment of tissue from each individual was preserved in silica gel for molecular analysis. In addition, at least one specimen from each site was pressed and mounted on a herbarium sheet to preserve anatomical features (vouchers were deposited in the herbarium of the Museum National d'Histoire Naturelle, Paris, France, nos. PC0533607-PC0533613).

To complete the sampling, two strains of reference (1330/1 and 1330/2) of $P$. littoralis from the Culture Collection of Algae and Protozoa (CCAP) isolated respectively in Roscoff in 1970 and 2002, were included in the analysis.

\section{DNA extraction, amplification and sequencing}

DNA was extracted from 5-10 mg of dry algal tissue using the Nucleospin® Multi-96 plant kit (Macherey-Nagel GmbH and Co. KG) according to the manufacturer's protocol except for the cell lysis buffer in which samples were left at room temperature for one hour rather than heating to $65^{\circ} \mathrm{C}$ for $30 \mathrm{~min}$. Sequences of three mitochondrial genes $\operatorname{cox} 1$ ( $658 \mathrm{nt}$ ), nad1 (800 nt) and atp9 (200 nt), and of the two plastid genes $r b c \mathrm{~L}(1300 \mathrm{nt})$ and $a t p \mathrm{~B}(630$ nt) were amplified and sequenced. Primers used and PCR reactions performed are described in Silberfeld et al. (2010). cox 1 and $r b c \mathrm{~L}$ genes were sequenced for all specimens (i.e., 140 
individuals of $P$. littoralis and two CCAP strains). For the other mitochondrial and chloroplast genes (nad1, atp9 and atp B) a subsample of 45 individuals of $P$. littoralis was used to confirm results obtained with the previous genes. PCR products were purified and sequenced by LGC genomics (Berlin, Germany). The obtained sequences were edited and aligned using Codoncode Aligner v. 3.7 (www.codoncode.com, Centerville, Massachusetts, USA).

\section{Phylogenetic approach}

Phylogenetic relationships among mitochondrial DNA (mtDNA) and chloroplastic DNA ( $c p$ DNA) haplotypes were reconstructed using median-joining networks with Network version 4.2.0.1 (Bandelt et al. 1999). Mismatch distribution were analyzed for cox 1 and $r b c \mathrm{~L}$ genes. Pairwise comparisons were calculated for each gene to determine the threshold between intraspecific and interspecific divergences (Puillandre et al. 2011).

\section{Population genetic approach}

Microsatellite markers developed for Ectocarpus siliculosus (Dillwyn) Lyngbye (Cock et al. 2010) were transferred to $P$. littoralis. Of the 60 microsatellites analyzed, 30 showed repeatable positive amplification, but only 10 showed a legible signal after sequencing

(Table 2). These 10 markers were used for the population analysis on the 140 specimens of P. littoralis according to the following method. PCR was carried out in a $10 \mu \mathrm{L}$ volume of the following components: $2 \mu \mathrm{L}$ of DNA template diluted 1:25, $150 \mu \mathrm{M}$ of dNTPs (Thermo Fisher Scientific Inc., Waltham, MA, USA), 30 pmol forward fluorescent-labelled primer FAM, Yakima Yellow (VIC), ATTO550 (NED) or ATTO565(PET) (Eurofins MWG Operon, Ebersberg, Germany), 30 pmol reverse primer (Eurofins MWG Operon, Ebersberg, Germany), $2.5 \mathrm{mM}$ of $\mathrm{MgCl}_{2}$ (Promega Corp.), 1 X GoTaq ${ }^{\circledR}$ Flexi Buffer (Promega Corp.), 
and 0.35 U GoTaq ${ }^{\circledR}$ DNA polymerase (Promega Corp.). PCR cycling included an initial denaturing step at $95^{\circ} \mathrm{C}$ for $5 \mathrm{~min}$, followed by 35 cycles at $95^{\circ} \mathrm{C}$ for $30 \mathrm{~s}, 50$ or $54^{\circ} \mathrm{C}$ for 30 $\mathrm{s}$ and, $72^{\circ} \mathrm{C}$ for $30 \mathrm{~s}$ with a final elongation step of $72^{\circ} \mathrm{C}$ for $10 \mathrm{~min}$. PCR products were pooled and diluted (1:10) and $2 \mu \mathrm{L}$ were added to a mixture containing 9.5 $\mu \mathrm{L}$ of Hi-Di formamide (Life Technologies Corporation) and $0.5 \mu \mathrm{L}$ of SM594 size standard (Mauger et al. 2012). This loading mix was denatured $\left(95^{\circ} \mathrm{C}\right.$ for $\left.5 \mathrm{~min}\right)$ and run in a $3130 \mathrm{XL}$ Genetic Analyzer (Life Technologies Corporation). Alleles were scored using GeneMapper ${ }^{\circledR}$ v. 4.0 (Applied Biosystems ${ }^{\mathrm{TM}}$ ).

Standard measures of genetic diversity were estimated using GenAlEx version 6.5 (Peakall and Smouse 2012): mean number of alleles per locus $\left(\mathrm{N}_{\mathrm{a}}\right)$ was calculated in 10 populations corresponding to cluster of individuals assigned to different cytotypes for each sample (Table 1). Expected heterozygosity $\left(\mathrm{H}_{\mathrm{e}}\right)$ was estimated when the number of individuals per cluster was higher than 10. Moreover, all pairs of loci across sites were tested for linkage disequilibrium using a Markov chain approximation of an exact test as implemented in GENEPOP web version 4.0.10 (Raymond and Rousset 1995) and the genetic structure between sampled populations was computed by calculating an estimate of $F_{\mathrm{ST}}$ (Weir \& Cockerham 1984). For each population, allele frequencies were calculated at all 10 loci. These data were summarized and statistically tested with a factorial correspondence analysis (FCA) performed using GENETIX software (Belkhir et al. 2003) and a principal component analysis (PCA) performed using PCA-GEN software (version 1.2; Goudet 1999). The statistical significance associated with each axis was evaluated after 10,000 randomizations. In a separate analysis, the most likely number of genetic clusters was inferred using STRUCTURE version 2.2 (Pritchard et al. 2000) on the seven sampled sites. This program was run under the admixture and independent allele frequency model using a Markov chain 
Monte Carlo length of 250000 steps after a burn-in of 50,000. The number of clusters (K) was determined by estimating the probability of the data $[\log \operatorname{Pr}(\mathrm{X} \mid \mathrm{K})]$ for runs with $\mathrm{K}=2$ 10, averaged over 20 independent runs. The value of $\mathrm{K}$ that most likely captured the major structure patterns in the data was determined as the smallest $\mathrm{K}$ at which average $\log \operatorname{Pr}(\mathrm{X} \mid \mathrm{K})$ estimates leveled out. For the selected K, results from replicate runs were averaged with CLUMPP version 1.1.2 (Jakobsson and Rosenberg 2007) and displayed graphically using DISTRUCT version 1.1 (Rosenberg 2004).

\section{RESULTS}

\section{Haplotypic diversity}

Sequence comparisons of the 5' end of the $\operatorname{cox} 1$ gene (658 nt) obtained for 142 specimens revealed a total of 30 polymorphic sites (up to $3.2 \%$ divergence) corresponding to 17 mitotypes (Fig. 2). These mitotypes were clearly separated into two distinct clusters, named MtA and MtB, with respectively 12 and 5 mitotypes (GenBank accession number: KM027317 to KM027333). Analysis of mismatch distributions of the cox 1 sequence, considering all the analyzed individuals is shown in Figure 2 (inset). The bimodal distribution (first peak centered on 2 differences and the second on 18 differences) confirmed the existence of a barcode gap (i.e., intergroup differences greater than intragroup differences) between cytoplasmic clusters MtA and MtB. A minimum divergence of 16 nucleotides (2.4\%) was observed between mitotypes of these two groups. Group MtB was mainly represented by three mitotypes (M1b, M2b and M3b) and one mitotype was unique, found in only one individual (M5b). In MtB, the intragroup haplotypic divergence ranged from 0 to $0.45 \%$. Group MtA was mostly represented by four mitotypes (M1a, M2a, M3a and M4a), with two mitotypes found in only one individual (M8a and M9a) and the 
intragroup haplotypic divergence ranged from 0 to $0.9 \%$. Similar results were obtained for other sequenced mitochondrial genes nad1 (1.9-2.1\% divergence between mitotypes; GenBank accession number: KP058512, KP058513 and KM057703 to KM057706) and atp9 (1.5-2.0\%; GenBank accession number: KM057708 to KM057710) with respectively 20 and 4 polymorphic sites (Figs. S1 and S2 in the Supporting Information). The sequence of one CCAP strain of Pylaiella littoralis (1330/1) corresponded to haplotype M1b of the MtB cluster, whereas the sequence of the 1330/2 strain corresponded to the haplotype M5a of the MtA cluster. Individuals with the cytoplasm MtA and MtB were found in all locations except in Concarneau (site at which sampling was done only once, in spring) where all individuals analyzed only had MtA mitotypes.

Analysis of $r b c \mathrm{~L}$ sequences (1321 nt) showed high chlorotype diversity (20 chlorotypes; GenBank accession number: KM057683 to KM057702) with 12 polymorphic sites (up to $0.7 \%$ divergence); nevertheless these chlorotypes did not cluster in conspicuous groups (Fig. 3). The two cytoplasmic groups MtA and MtB, resulting from cox 1 clustering, shared $47 \%$ of the chlorotypes (7 of the 15 haplotypes found in at least two individuals), whereas six were unique to the MtA group (CL8, CL9, CL13, CL14, CL16 and CL17) and seven were unique to the MtB group (CL3, CL4, CL10, CL11, CL15, CL18 and CL20). Group MtB was mostly represented by two chlorotypes (CL3 and CL4), whereas Group MtA was represented mostly by a single haplotype (CL1). Results for the atp B gene (GenBank accession number: KM057707) were congruent with those of $r b c \mathrm{~L}$, showing one haplotype shared by MtA and MtB.

\section{Temporal distribution of the two mitochondrial clusters}

Although both mitotype clusters MtA or MtB were found together in the field (except in October), a seasonal shift was observed in their frequencies. The maximum frequency of 
individuals with MtA cytoplasm (83.6\%) was found in spring (April), whereas the maximum frequency of individuals with MtB cytoplasm (63.3\%) was observed in autumn (October; Table 1).

\section{Structure of populations}

All the microsatellite genotypes observed in this study were heterozygous for at least one microsatellite locus. Based on the mitochondrial clusters, individuals were assigned to the two groups, MtA and MtB (Table 1). The total number of alleles observed over all samples ranged from 18 to 52 from the least to the most polymorphic locus (M028-1 and M194, respectively, Table 2). For localities with more than 10 samples, the mean number of alleles per locus $\left(\mathrm{N}_{\mathrm{a}}\right)$ ranged from 6.7 to 14 (Table 1). Over a total of 353 alleles, $153(43 \%)$ were found only in the MtB cluster and 94 (26\%) were found only in the MtA cluster (i.e. private alleles) with frequencies oscillating between 0.014 and 0.208 . Gene diversity $\left(\mathrm{H}_{\mathrm{e}}\right)$ ranged from 0.608 to 0.741 . No repeat multilocus genotypes and no multilocus monomorphic genotypes were detected. There was no evidence of linkage disequilibrium between pairs of loci (data not shown) except for one pair of loci (M105-1/M194), which remained significant after sequential Bonferroni correction.

The results of the PCA (Fig. 4a) showed a significant overall $F_{\text {ST }}$ value of $0.22(\mathrm{P}=0.0001)$. The first two PCA axes were significant and explained 64\% of the variance: axis 1 accounted for $50.8 \%$ of the variance and axis 2 accounted for $13.6 \%$ of the variance. Axis 1 separated MtA samples from MtB samples. The factorial correspondence analysis (FCA) confirmed the partitioning into two main groups of individuals along axis 1 corresponding to mitotypes MtA and MtB (Fig. 4b). Within the MtB mitotype group, individuals were partitioned according to sampling date, whatever their origin. Individuals sampled in autumn in St. Malo and in Roscoff clustered together, whereas individuals sampled in spring in these 
sites were intermediate between the MtB individuals and the MtA mitotype group (Fig. 4b). Again, the two FCA axes were significant and explained $45 \%$ of the variance: axis 1 accounted for $28 \%$ of the variance $\left(F_{\mathrm{ST}}=0.11, \mathrm{P}=0.001\right)$ and axis 2 accounted for $17 \%$ of the variance $\left(F_{\mathrm{ST}}=0.03, \mathrm{P}=0.815\right)$. Genetic differentiation between pairs of samples $\left(F_{\mathrm{ST}}\right)$ (Table 3) ranged from 0.07 (samples 4 vs. 1) to 0.24 (samples $4 v s .7$ ). The lowest $F_{\mathrm{ST}}$ values were observed between samples assigned to the same mitotype, whereas the highest values were observed for samples assigned to mitotypes sampled in spring and in autumn. Regarding the analysis of structure, the $\Delta \mathrm{K}$ criterion separated the seven spatiotemporal samples into two "clusters" $(\mathrm{K}=2)$. The proportion of genotypes assigned to each of the two clusters is given in Figure 5. The first cluster included virtually all the MtA samples and the second cluster includes MtB samples. This result confirms the PCA (and FCA) results, which grouped these samples along axis 1 (Fig. 4). However, when individuals were sampled together in the same location (2, 3 and 6), admixture was observed. Five individuals from Dinard (sample 3) with MtB mitotypes were assigned to the first (MtA-dominant) cluster (Fig. 5).

\section{DISCUSSION}

Our findings revealed that Pylaiella littoralis comprises two cryptic species that have thus far been overlooked in Brittany, since only one had been recognized after the work of Feldmann (1954). Both phylogenetic inferences and population genetic studies highlighted the existence of two genetic entities under the name of $P$. littoralis. The level of coxl divergence observed between the two mitochondrial clusters (MtA and MtB) of P. littoralis $(2.4 \%-3.2 \%)$, was substantially greater than values detected within a cluster $(0.0 \%-0.9 \%)$. Thus, our results are in agreement with the recent proposals on Desmaretiales (Yang et al. 2014) and Ectocarpales (Peters et al. 2015 in press) that estimated species-level cut-off at 
divergence of about $1.2 \%$ and $1.8 \%$ respectively. Furthermore, the common chlorotypes observed in the two $P$. littoralis species suggest that differentiation is recent. Therefore, these two closely related species of the $P$. littoralis complex should be regarded as sibling species (Bickford et al. 2007).

Our results confirm that chloroplastic markers have lower mutation rates than mitochondrial markers (e.g., for brown algae: Presting 2006, Engel et al. 2008, Tellier et al. 2009).

Difference in resolution found between mitochondrial and plastid markers can be explained by the difference in effective population size (Palumbi et al. 2001). In Phaeophyceae, mitochondria are maternally inherited (but see Hoarau et al. 2009 in Fucus species), whereas plastid may be partly biparentally inherited (Peters et al. 2004). Peters et al. (2004) suggested that the biparental chloroplast inheritance observed in Ectocarpus siliculosus may be widespread in isogamous brown algae. For example, biparental chloroplast inheritance is observed in Scytosiphon lomentaria (Lyngbye) Link (Kato et al. 2006). However, although the genus of Pylaiella is phylogenetically related to Ectocarpus and Scytosiphon, no information is available on chloroplast inheritance.

Nuclear microsatellite markers consistently recovered the two well-supported cox 1 mitochondrial clusters (i.e., MtA and MtB), suggesting that gene flow is limited between taxa. Likewise, we observed high values of genetic differentiation $\left(F_{\mathrm{ST}}\right)$ between pairs of allopatric populations $(1,4,5,7)$ that were assigned to different clusters. However, when their spatio-temporal distribution intersects (i.e., sympatric populations in which individuals MtA and individuals MtB were sampled simultaneously in spring and at the same site), admixtures was found (Fig. 5). The FCA showed that individuals with MtB mitotypes sampled in the spring were genotypically intermediate to the MtA group and the other MtB mitotypes (Fig. 4). These results suggest that there is some contemporary gene flow 
reflecting the fact that reproductive isolation is not complete. However, we argue that effective gene flow is too low to compromise the integrity of these two genetic entities. Interspecific gene flow is well documented in some other brown algae, such as in the genus Fucus resulting from hybridization and introgression (Wallace et al. 2004, Billard et al. 2005, 2010, Engel et al. 2005, Coyer et al. 2007, 2011, Zardi et al. 2011). For example, Engel et al. (2005), using microsatellite markers, identified about $13 \%$ of hybrids in sympatric natural populations of Fucus spiralis Linnaeus and Fucus vesiculosus Linnaeus. Coyer et al. (2011) suggest that despite introgression, the maintenance of species integrity of F. spiralis, F. vesiculosus and Fucus guiryi G.I. Zardi, K.R. Nicastro, E.S. Serrão \& G.A. Pearson is due to a combination of limited gamete dispersal capacities, reproductive system as well as ecological factors reinforcing the divergence between species. In externally fertilizing species, asynchronous gamete release between related taxa is considered the major prezygotic barrier to hybridization (Levitan et al. 2004, Monteiro et al. 2012). In our study, although the two sibling species are broadly sympatric, a temporal niche segregation may promote reproductive isolation. Our observations showed that the species characterized by the MtA mitotype was present in spring and absent in autumn whereas, the other species characterized by the MtB mitotype, was mainly observed in autumn. Although more accurate information on reproduction is not available, these apparent phenological differences may act as a prezygotic barrier favoring reproductive isolation. Moreover, this difference in phenology implies that both species probably face different biotic (e.g., grazers, competition, host) and abiotic parameters (e.g. temperature, day length, irradiance) during their peak of abundance. Such differences probably have important evolutionary consequences for reproductive isolation and sympatric speciation.

Furthermore, hybridization in natural populations depends on both intrinsic (i.e., environment independent) and extrinsic reproductive barriers. Extrinsic barriers can greatly 
affect the success of interspecific crosses, either by favoring prezygotic barriers (phenology, synchrony of spawning) or by limiting the success of hybrids via habitat-dependent or negative frequency-dependent selection (Tellier et al. 2011).

The life history of the genus Pylaiella remains poorly known and controversial, as several patterns have been observed (Müller and Stache 1989). Kylin (1933) noticed the occurrence of sporophytes and gametophytes in natural populations in Sweden and Knight (1923) demonstrated the alternation sporophytes and gametophytes in culture, in material from Isle of Man (Irish Sea). However, in different strains from Helgoland (North Sea) and Chile (Pacific), this species reproduces only asexually (Müller and Stache 1989). The microsatellite results obtained in our study suggest that the two sibling species of Pylaiella littoralis reproduce mainly sexually. Moreover, it is noteworthy in our study that the two cryptic species showed high values of gene diversity $\left(\mathrm{H}_{\mathrm{e}}\right)$, suggesting that these species are characterized by large populations. The range of genetic diversity within populations was similar to that of microsatellite data in kelps (Valero et al. 2011).

In conclusion, our study illustrates that the combination of phylogenetic and population genetics is a powerful approach for understanding and delimiting species status in seaweed. Two sibling species were detected in P. littoralis as distinct genetic entities with limited gene flow. We nevertheless did not assign names to the two species uncovered in this study because the genus Pylaiella encompasses roughly 90 specific and intraspecific taxa (Guiry and Guiry 2014), all of which would have to be regarded as possible names of the two species in application of Article 11 of the International Code of Nomenclature for algae, fungi, and plants (McNeill et al. 2012). Unfortunately, we are presently unable to identify putatively diagnostic characters for either species uncovered in this study and or in the type materials, which prevents bridging the gap between the classical taxonomical approach and 
modern species delimitation methods. Our study highlights how complementary barcoding and population genetics analyses can help solve taxonomic questions at short phylogenetic distances. However, further understanding of speciation and of the maintenance of integrity of these different species requires phenological, biological, ecological and genetic experiments to document sexual reproduction and to reveal the differences in their ecological tolerance.

\section{Acknowledgments}

We thank M. Valero, A. Peter, S. de Goer, B. de Reviers and C. Engel for helpful comments. We are also most grateful to the Biogenouest Genomics core facility for its technical support. This study was partially supported by grants from the French Ministry for Economy, Industry and Employment and the Brittany Regional Council through the project AQUACTIFS “Convention de soutien de l'état à des actions de recherche et d'innovation par voie de subvention - Fonds de compétitivité des entreprises", the project IDEALG (ANR-10-BTBR-04) 'Investissements d'avenir, Biotechnologies-Bioressources' and ASSEMBLE grant no. 227799. Special thanks to CCAP for providing strains of Pylaiella littoralis. 
Table 1. Characteristics of Pylaiella littoralis samples; $\mathrm{N}_{\mathrm{T}}$ total number of sampled individuals, $\mathrm{N}$ : number of individuals assigned to mitotype MtA or MtB according to cox1 sequences, $\mathrm{N} \operatorname{cox} 1$ : number of mitotypes cox $1, \mathrm{~N} r b c \mathrm{~L}$ : number of chlorotypes $r b c \mathrm{~L}, \mathrm{~N}_{\mathrm{a}}$ : mean number of alleles per microsatellite locus; $\mathrm{H}_{\mathrm{e}}$ : microsatellite multilocus non-biased expected heterozygosity; —: no data.

\begin{tabular}{|c|c|c|c|c|c|c|c|c|c|}
\hline Location & $\mathrm{N}_{\mathrm{T}}$ & $\begin{array}{l}\text { Sample } \\
\text { name }\end{array}$ & Date & Mitotype & $\mathrm{N}$ & $\begin{array}{l}\mathrm{N} \\
\cos 1\end{array}$ & $\begin{array}{l}\mathrm{N} \\
r b c \mathrm{~L}\end{array}$ & $\mathrm{~N}_{\mathrm{a}}$ & $\mathrm{H}_{\mathrm{e}}$ \\
\hline \multirow[t]{4}{*}{ Saint Malo (ST) } & 41 & & & & & & & & \\
\hline & & 1 & 15 October 2008 & $\mathrm{MtB}$ & 32 & 4 & 6 & 14 & 0.672 \\
\hline & & & 15 June 2009 & $\mathrm{MtB}$ & 5 & 2 & 2 & 4.8 & - \\
\hline & & 2 & 15 June 2009 & MtA & 4 & 4 & 4 & 3.9 & - \\
\hline \multirow[t]{3}{*}{ Dinard (DI) } & 16 & & & & & & & & \\
\hline & & & 21 April 2010 & MtB & 12 & 2 & 6 & 6.7 & 0.694 \\
\hline & & 3 & 21 April 2010 & MtA & 4 & 2 & 3 & 3.6 & - \\
\hline \multirow[t]{5}{*}{ Roscoff (RO) } & 62 & & & & & & & & \\
\hline & & 4 & 26 October 2008 & $\mathrm{MtB}$ & 18 & 2 & 1 & 9.6 & 0.658 \\
\hline & & 5 & 29 April 2009 & MtA & 26 & 6 & 9 & 9.6 & 0.608 \\
\hline & & 6 & 14 May 2010 & $\mathrm{MtB}$ & 12 & 3 & 4 & 8.5 & 0.741 \\
\hline & & 0 & 14 May 2010 & MtA & 6 & 3 & 1 & 4.4 & - \\
\hline \multirow[t]{2}{*}{ Concarneau (CO) } & 21 & & & & & & & & \\
\hline & & 7 & 19 April 2011 & MtA & 21 & 2 & 1 & 9.6 & 0.617 \\
\hline
\end{tabular}


Table 2. List and characteristics of microsatellite makers used for population analysis. $\mathrm{N}_{\mathrm{a}}$ number of alleles detected at each locus.

\begin{tabular}{|c|c|c|c|c|c|c|c|}
\hline Marker name & $\begin{array}{l}\text { Gene } \\
\text { Location }\end{array}$ & Length & Left primer $\left(5^{\prime}-3^{\prime}\right)$ & Right primer (5'-3') & $\begin{array}{l}\mathrm{Tm} \\
\left({ }^{\circ} \mathrm{C}\right)\end{array}$ & $\begin{array}{l}\text { Product } \\
\text { size (bp) }\end{array}$ & $\mathrm{N}_{\mathrm{a}}$ \\
\hline M-168 & No Gene & 76 & AAACTACACCAACGAAATCAA & AАCСААССТССТССААТC & 50 & 279 & 37 \\
\hline M-239-3 & No Gene & 66 & ATAAGACTCAGCAAGAGGCAG & CATTGAACGACAAATCCC & 50 & 241 & 42 \\
\hline M-383-1 & Intron & 76 & GGGTGAGACAGTAGTAGCAGG & CTCGGAACAGGAAGGTTT & 50 & 240 & 50 \\
\hline M-392 & Intron & 137 & CTTGTGTGCGTGCTGTTG & GACTTAGATTTCCGTGTCCTC & 54 & 304 & 21 \\
\hline M-199-3 & No Gene & 42 & GCAGTAGTAGCAGTAGTCGG & TTCATTGTGTTCTTCTTCGTC & 50 & 227 & 18 \\
\hline M-231 & Exon & 91 & CGGTGACAGATAGACAGACAG & CCCTCAGTTGTTCCTCAAGT & 50 & 193 & 38 \\
\hline M-028-1 & Intron & 126 & ATTACAGCAAGGACAAATGG & TAAGAAGGACTGGTGGAGG & 54 & 262 & 18 \\
\hline M-105-1 & Intron & 106 & CTACTCTCCGCAATAAAGACA & AGGTATGAACACGACGACAG & 50 & 298 & 45 \\
\hline M-138 & No Gene & 69 & TGTCTGAATGTTGATGTGTGT & AGGGTAGGCAAAGAATGG & 50 & 271 & 33 \\
\hline M-194 & Intron & 91 & GTCGGATGACGAGGACTT & AATGTTTATTTAGGCTTTGCT & 50 & 296 & 51 \\
\hline
\end{tabular}


Table 3. Pairwise population genetic differentiation (pairwise $F_{\mathrm{ST}}$ estimates). All $F_{\mathrm{ST}}$ values were significant $(\mathrm{P}<0.001)$. The numbers $(1$ to 7$)$ refer to the sample name (see Table 1$)$. The values of $F_{\mathrm{ST}}$ were calculated only for populations with more than 10 individuals $(\mathrm{N}>10)$. All $F_{\mathrm{ST}}$ values were significant $(\mathrm{P}<0.001)$. In grey, the highest $F_{\mathrm{ST}}$ values between pairs of samples assigned to different mitotypes.

\begin{tabular}{|c|c|c|c|c|c|c|}
\hline & $\begin{array}{c}5 \\
\mathrm{MtA}\end{array}$ & $\begin{array}{c}7 \\
\mathrm{MtA}\end{array}$ & $\begin{array}{c}1 \\
\mathrm{MtB}\end{array}$ & $\begin{array}{c}4 \\
\mathrm{MtB}\end{array}$ & $\begin{array}{c}6 \\
\mathrm{MtB}\end{array}$ & $\begin{array}{c}3 \\
\mathrm{MtB}\end{array}$ \\
\hline $\begin{array}{c}5 \\
\mathrm{MtA}\end{array}$ & 0 & 0.09 & 0.20 & 0.22 & 0.15 & 0.15 \\
\hline $\begin{array}{c}7 \\
\mathrm{MtA}\end{array}$ & & 0 & 0.21 & 0.24 & 0.14 & 0.15 \\
\hline $\begin{array}{c}1 \\
\mathrm{MtB}\end{array}$ & & & 0 & 0.07 & 0.09 & 0.11 \\
\hline $\begin{array}{c}4 \\
\mathrm{MtB}\end{array}$ & & & & 0 & 0.08 & 0.11 \\
\hline $\begin{array}{c}6 \\
\mathrm{MtB}\end{array}$ & & & & & 0 & 0.08 \\
\hline $\begin{array}{c}3 \\
\mathrm{MtB}\end{array}$ & & & & & & 0 \\
\hline
\end{tabular}

Legends

Figure 1. Map of the four sampled locations along the Brittany coast (France), Saint Malo $\left(48^{\circ} 38.912^{\prime} \mathrm{N}, 2^{\circ} 1.819^{\prime} \mathrm{W}\right)$, Dinard (48³7.593’ N $\left.2^{\circ} 02.600^{\prime} \mathrm{W}\right)$, Roscoff (4843.658’ N, $\left.3^{\circ} 59.260^{\prime} \mathrm{W}\right)$ and Concarneau $\left(47^{\circ} 51.193^{\prime} \mathrm{N} 3^{\circ} 55.055^{\prime} \mathrm{W}\right)$. Numbers in parentheses (1-7) indicate the s e name (see Table 1).

Figure 2. Median-joining network of the relationships among haplotypes of the cox 1 coding sequence from 140 Pylaiella littoralis individuals. Circle size is proportional to haplotype frequency. Lines joining haplotypes indicate mutation events. Colors are coded by sampling location. Perpendicular bars indicate additional mutations. Inset shows a mismatch 
distribution histogram for the cox 1 mitochondrial haplotypes, with the frequency of the observed number of pairwise differences between Pylaiella littoralis individuals.

Figure 3. Median-joining network of the relationships among haplotypes of the $r b c \mathrm{~L}$ coding sequence from 140 individuals of Pylaiella littoralis. Circle size is proportional to haplotype frequency. Lines joining haplotypes indicate mutation events. Colors are coded by sampling location. Perpendicular bars indicate additional mutations. $m v$ : median vector, hypothesized sequence (often ancestral) which is required to connect existing sequences within the network with maximum parsimony. Inset shows the mismatch distribution histogram for chloroplastic haplotypes, with the frequency of the observed number of pairwise differences between Pylaiella littoralis individuals.

Figure 4. (a) Principal component analysis (PCA) on population allele frequencies and (b) factorial correspondence analysis (FCA) on individual multilocus genotypes. These two analyses were conducted on 10 microsatellite markers for 10 subsamples from Brittany, France. Sampling locations are color-coded. Populations and individuals assigned to mitotype MtA or MtB are indicated by triangles and circles, respectively. Inertia of each axis is given in parentheses. For a key to sample names, see Table 1.

Figure 5. Bayesian clustering of microsatellite data obtained for all samples (considering all 10 loci). Each individual is represented by a thin vertical bar partitioned into $\mathrm{K}=2$ clusters, (in black and white) representing the individual's estimated nuclear admixture coefficient. Circles at the top or the bottom of each individual bar indicates the individual's mitotype (MtA, black; MtB, white). The seven samples are separated by vertical gray lines (see Table $1)$. 


\section{Supplementary material}

Figure S1. Median-joining network of the relationships among haplotypes of the atp 9 coding sequence from 45 Pylaiella littoralis individuals. Circle size is proportional to haplotype frequency. Lines joining haplotypes indicate mutation events. Colors are coded by sampling location. Perpendicular bars indicate additional mutations. $\mathrm{N}$ represents the number of Pylaiella littoralis individuals. MtA and MtB refer to the group defined with the cox 1 gene results.

Figure S2. Median-joining network of the relationships among haplotypes of the nad1 coding sequence from 45 individuals of Pylaiella littoralis. Circle size is proportional to haplotype frequency. Lines joining haplotypes indicate mutation events. Colors are coded by sampling location. Perpendicular bars indicate additional mutations. $m v$ : median vector, hypothetical sequence (often ancestral) which is required to connect existing sequences within the network with maximum parsimony. $\mathrm{N}$ represents the number of Pylaiella littoralis individuals. MtA and MtB refer to the group defined with the cox 1 gene results.

\section{References}

Bandelt, H. J., Forster, P. \& Röhl, A. 1999. Median-joining networks for inferring intraspecific phylogenies. Mol. Biol. Evol. 16:37-48.

Belkhir, K., Borsa, P., Chikhi, L., Raufaste, N. \& Bonhomme, F. 2003. GENETIX 4.05, logiciel sous Windows TM pour la génétique des populations. www.genetix.univ-montp2.fr. 
Bickford, D., Lohman, D. J., Sodhi, N. S., Ng, P. K. L., Meier, R., Winker, K., Ingram, K. K. \& Das, I. 2007. Cryptic species as a window on diversity and conservation. Trends Ecol. Evol. 22:148-55.

Billard, E., Daguin, C., Pearson, G., Serrão, E., Engel, C. \& Valero, M. 2005. Genetic isolation between three closely related taxa: Fucus vesiculosus, F. spiralis, and F. ceranö̈des (Phaophyceae). J. Phycol. 41:900-905.

Billard, E., Serrão, E., Pearson, G., Destombe, C. \& Valero, M. 2010. Fucus vesiculosus and spiralis species complex: a nested model of local adaptation at the shore level. Mar. Ecol. Prog. Ser. 405:163-174.

Bolton, J. J. 1979a. The taxonomy of Pilayella littoralis (L.) Kjellm. (Phaeophyta, Ectocarpales) in the British Isles, a numerical approach. Br. Phycol. J. 14:317-325.

Bolton, J. J. 1979b. Estuarine adaptation in populations of Pilayella littoralis (L.) Kjellm. (Phaeophyta, Ectocarpales). Estuar. Coast. Mar. Sci. 9:273-280.

Cock, J. M., Sterck, L., Rouzé, P., Scornet, D., Allen, A. E., Amoutzias, G., Anthouard, V., Artiguenave, F., Aury, J. M., Badger, J. H., Beszteri, B., Billiau, K., Bonnet, E., Bothwell, J. H., Bowler, C., Boyen, C., Brownlee, C., Carrano, C. J., Charrier, B., et al. 2010. The Ectocarpus genome and the independent evolution of multicellularity in brown algae. Nature 465:617-621. 
Coyer, J. A., Hoarau, G., Stam, W. T. \& Olsen, J. L. 2007. Hybridization and introgression in a mixed population of the intertidal seaweeds Fucus evanescens and F. serratus. J. Evol. Biol. 20:2322-2333.

Coyer, J. A., Hoarau, G., Costa, J. F., Hogerdijk, B., Serrão, E. A., Billard, E., Valero, M., Pearson, G. A. \& Olsen, J. L. 2011. Evolution and diversification within the intertidal brown macroalgae Fucus spiralis/F. vesiculosus species complex in the North Atlantic. Mol. Phylogenet. Evol. 58:283-296.

Engel, C. R., Daguin, C. \& Serrão, E. A. 2005. Genetic entities and mating system in hermaphroditic Fucus spiralis and its close dioecious relative F. vesiculosus (Fucaceae, Phaeophyceae). Mol. Ecol. 14:2033-2046.

Engel, C. R., Billard, E., Voisin, M. \& Viard, F. 2008. Conservation and polymorphism of mitochondrial intergenic sequences in brown algae (Phaeophyceae). Eur. J. Phycol. 43:195205.

Feldmann, J. 1954. Inventaire de la flore marine de Roscoff. Algues, champignons, lichens et spermatophytes. Travaux Station Biologique de Roscoff, suppl. 6:152 pp.

Fritsch, F. E. 1952. The structure and reproduction of the Algae. Cambridge University Press, London, vol. 2, 939 pp.

Goudet, J. 1999. PCA-GEN: Principal Component Analysis on gene frequency data, version 1.2. Population Genetics Laboratory, University of Lausanne, Switzerland. 
Guiry, M. D. \& Guiry, G. M. 2014. AlgaeBase. world-wide electronic publication. Available at: http://www.algaebase.org (last accessed 15 April 2014).

Hoarau, G., Coyer, J. A. \& Olsen, J. L. 2009. Paternal leakage of mitochondrial DNA in a Fucus (Phaeophyceae) hybrid zone. J. Phycol. 45:621-624.

Jakobsson, M. \& Rosenberg, N. A. 2007. CLUMPP: a cluster matching and permutation program for dealing with label switching and multimodality in analysis of population structure. Bioinformatics 23:1801-6.

Kato, Y., Kogame, K., Nagasato, C. \& Motomura, T. 2006. Inheritance of mitochondrial and chloroplast genomes in the isogamous brown alga Scytosiphon lomentaria (Phaeophyceae). Phycol. Res. 54:65-71.

Kiirikki, M. \& Lehvo, A. 1997. Life strategies of filamentous algae in the northern Baltic proper. Sarsia 82:259-267.

Knight, M. 1923. Studies in the Ectocarpaceae I. The life-history and cytology of Pylaiella littoralis (L.) Kjellm. Trans. R. Soc. Edinburgh 53:353-361.

Kornmann, P. \& Sahling, P.-H. 1977. Meeresalgen von Helgoland. Helgoländer Wiss. Meeresunters 29:1-289.

Kornmann, P. 1990. Pilayella macrocarpa Foslie (Ectocarpales, Phaeophyceae) in Helgoland and the rejection of Pilayella varia Kjellman. Bot. Mar. 33:257-259. 
Kylin, H. 1933. Über die entwicklungsgeschichte der Phaeophyceen, von Harald Kylin. H. Ohlssons Buchdruckerei, Lund, 102 pp.

Leliaert, F., Verbruggen, H., Vanormelingen, P., Steen, F., López-Bautista, J. M., Zuccarello, G. C. \& De Clerck, O. 2014. DNA-based species delimitation in algae. Eur. J. Phycol. 49:179-196.

Levitan, D. R., Fukami, H., Jara, J., Kline, D., McGovern, T. M., McGhee, K. E., Swanson, C. A. \& Knowlton, N. 2004. Mechanisms of reproductive isolation among sympatric broadcast-spawning corals of the Montastraea annularis species complex. Evolution. $58: 308-323$.

Mauger, S., Couceiro, L. \& Valero, M. 2012. A simple and cost-effective method to synthesize an internal size standard amenable to use with a 5-dye system. Prime Res. Biotechnol. 2:40-46.

Mayden, R. L. 1997. A hierarchy of species concepts : the denouement in the saga of the species problem. In M. F. Claridge, H. A. Dawah, and M. R. W. [Eds.] Species: the units of biodiversity. Chapman and Hall, New York, USA, pp. 381-424.

McDevit, D. C. \& Saunders, G. W. 2009. On the utility of DNA barcoding for species differentiation among brown macroalgae (Phaeophyceae) including a novel extraction protocol. Phycol. Res. 57:131-141.

Mcneill, J., Barrie, F. R., Buck, W. R., Demoulin, V., Greuter, W., Hawksworth, D. L., Herendeen, P. S., Knapp, S., Marhold, K., Prado, J., Prud'homme van reine, W. F., Smith, 
G. F., Wiersema, J. H. \& Turland, N. J. [Eds.]. 2012. International Code of Nomenclature for algae, fungi, and plants (Melbourne Code) adopted by the eighteenth international botanical congress Melbourne, Australia, July 2011. Koeltz Scientific Books, Melbourne, $240 \mathrm{pp}$.

Monteiro, C. A., Serrão, E. A. \& Pearson, G. A. 2012. Prezygotic barriers to hybridization in marine broadcast spawners: reproductive timing and mating system variation. PLoS One 7: e35978.

Müller, D. G. \& Stäche, B. 1989. Life history studies on Pilayella littoralis (L.) Kjellman (Phaeophyceae, Ectocarpales) of different geographical origin. Bot. Mar. 32:71-78.

Newton, L. 1931. A handbook of the British seaweeds. British Museum (Natural History), London, $478 \mathrm{pp}$.

Palumbi, S. R., Cipriano, F. \& Hare, M. P. 2001. Predicting nuclear gene coalescence from mitochondrial data: the three-times rule. Evolution. 55:859-868.

Peakall, R. \& Smouse, P. E. 2012. GenAlEx 6.5: genetic analysis in Excel. Population genetic software for teaching and research--an update. Bioinformatics 28:2537-2539.

Peters, A. F., Scornet, D., Müller, D. G., Kloareg, B. \& Cock, J. M. 2004. Inheritance of organelles in artificial hybrids of the isogamous multicellular chromist alga Ectocarpus siliculosus (Phaeophyceae). Eur. J. Phycol. 39:235-242. 
Peters, A. F., Couceiro, L., Tsiamis, K., Küpper, F. C. \& Valero, M. 2015. Barcoding of cryptic stages of marine brown algae isolated from incubated substratum reveals high diversity in Acinetosporaceae (Ectocarpales, Phaeophyceae). Cryptogam. Algol. In press.

Presting, G. G. 2006. Identification of conserved regions in the plastid genome : implications for DNA barcoding and biological function. Can. J. Bot. 84:1434-1443.

Pritchard, J. K., Stephens, M. \& Donnelly, P. 2000. Inference of population structure using multilocus genotype data. Genetics 155:945-959.

Puillandre, N., Lambert, A., Brouillet, S. \& Achaz, G. 2011. ABGD, Automatic Barcode Gap Discovery for primary species delimitation. Mol. Ecol. 21:1864-1877.

Raymond, M. \& Rousset, F. 1995. GENEPOP (Version 1.2): Population Genetics Software for Exact Tests and Ecumenicism. J. Hered. 86:248-249.

Rosenberg, N. A. 2004. DISTRUCT: a program for the graphical display of population structure. Mol. Ecol. Notes 4:137-138.

Ruprecht, F.J. 1850. Algae Ochotenses: Die ersten sicheren Nachrichten über die Tange des Ochotskischen Meeres. Buchdruckerei der Kaiserlichen Akademie der Wissenschaften, St Petersburg, $243 \mathrm{pp}$.

Russell, G. 1963. A study in populations of Pylaiella littoralis. J. Mar. Biol. Assoc. United Kingdom 43:469-483. 
Russell, G. 1967. The ecology of some free-living Ectocarpaceae. Helgol. Mar. Res. 15: $155-162$.

Siemer, B. L. \& Pedersen, P. M. 1995. The taxonomic status of Pilayella littoralis, P. varia and P. macrocarpa (Pilayellaceae, Fucophyceae). Phycologia 34:257-266.

Silberfeld, T., Leigh, J. W., Verbruggen, H., Cruaud, C., de Reviers, B. \& Rousseau, F. 2010. A multi-locus time-calibrated phylogeny of the brown algae (Heterokonta, Ochrophyta, Phaeophyceae): investigating the evolutionary nature of the "brown algal crown radiation". Mol. Phylogenet. Evol. 56:659-674.

Silva, P. C., Lamy, D., Loiseaux-de Goër, S. \& Reviers, B. de 1999. Proposal to conserve the name Pylaiella bory (Phaeophyceae) with a conserved spelling. Taxon 48:139-140.

Sites Jr, J. W. \& Marshall, J. C. 2003. Delimiting species: a Renaissance issue in systematic biology. Trends Ecol. Evol. 18:462-470.

Tellier, F., Meynard, A. P., Correa, J. a, Faugeron, S. \& Valero, M. 2009. Phylogeographic analyses of the $30^{\circ} \mathrm{S}$ south-east Pacific biogeographic transition zone establish the occurrence of a sharp genetic discontinuity in the kelp Lessonia nigrescens: vicariance or parapatry? Mol. Phylogenet. Evol. 53:679-693.

Tellier, F., Faugeron, S. \& Valero, M. 2011. Possible role of a mitochondrial genome rearrangement in maintaining the spatial segregation of two cryptic species of the Lessonia nigrescens species complex. Cah. Biol. Mar. 52:371-383. 
Tronholm, A., Steen, F., Tyberghein, L., Leliaert, F., Verbruggen, H., Antonia Ribera

Siguan, M. \& De Clerck, O. 2010. Species delimitation, taxonomy, and biogeography of Dictyota in Europe (Dictyotales, Phaeophyceae). J. Phycol. 46:1301-1321.

Valero, M., Destombe, C., Mauger, S., Ribout, C., Engel, C. R., Daguin-Thiebaut, C. \& Tellier, F. 2011. Using genetic tools for sustainable management of kelps: a literature review and the example of Laminaria digitata. Cah. Biol. Mar. 52:467-483.

Wallace, A. L., Klein, A. S. \& Mathieson, A. C. 2004. Determining the affinities of salt marsh Fucoids using microsatellite markers: evidence of hybridization and introgression between two species of Fucus (Phaeophyta) in a Maine estuary. J. Phycol. 40:1013-1027.

Weir, B. S. \& Cockerham, C. C. 1984. Estimating F-Statistics for the analysis of population structure. Evolution 38:1358-1370.

Yang, E. C., Peters, A. F., Kawai, H., Stern, R., Hanyuda, T., Bárbara, I., Müller, D. G., Strittmatter, M., van Reine, W. F. P. \& Küpper, F. C. 2014. Ligulate Desmarestia (Desmarestiales, Phaeophyceae) revisited: D. japonica sp. nov. and D. dudresnayi differ from D. ligulata. J. Phycol. 50:149-166.

Zardi, G. I., Nicastro, K. R., Canovas, F., Costa, J. F., Serrão, E. A. \& Pearson, G. A. 2011. Adaptive traits are maintained on steep selective gradients despite gene flow and hybridization in the intertidal zone. PLoS One 6:e19402. 


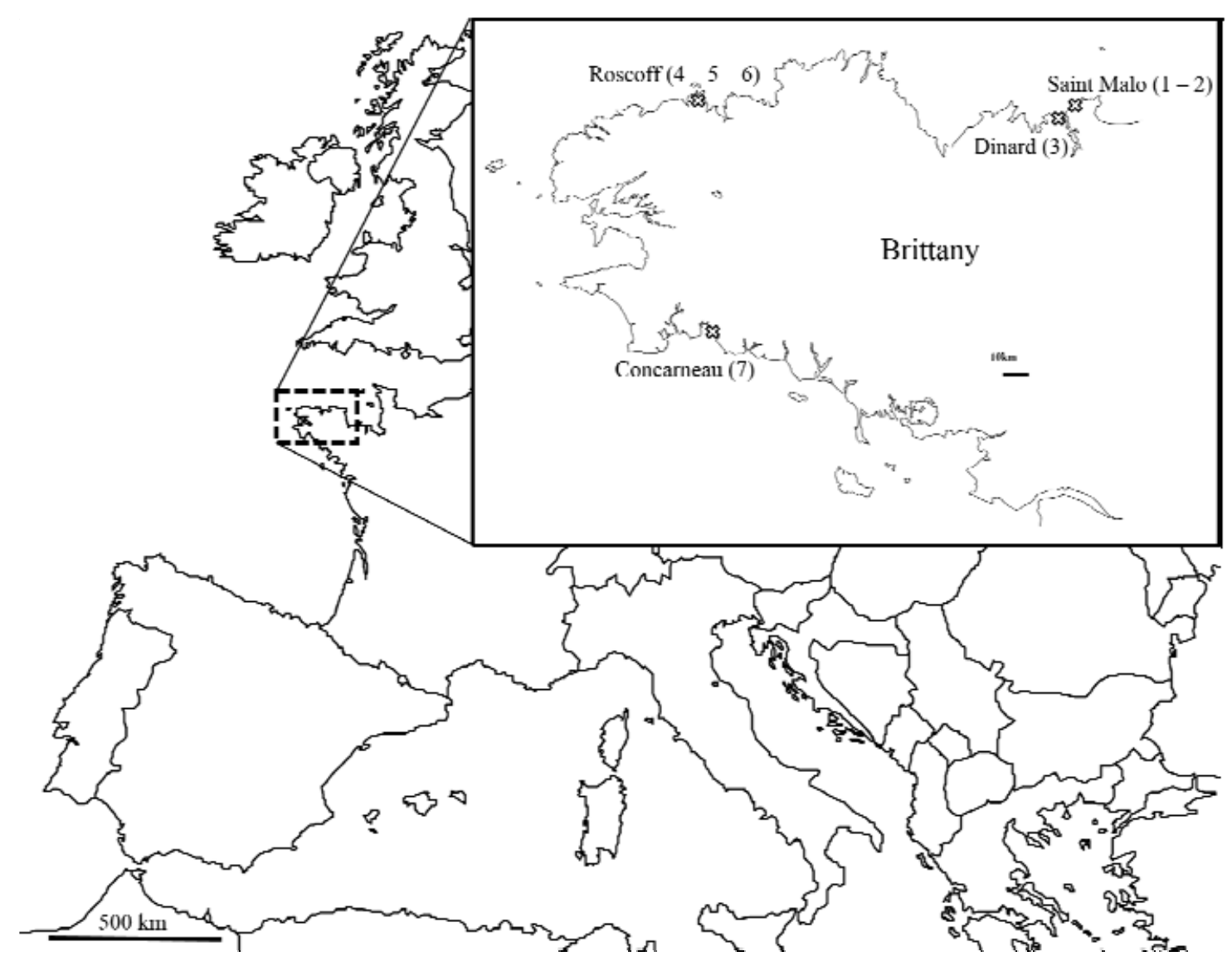



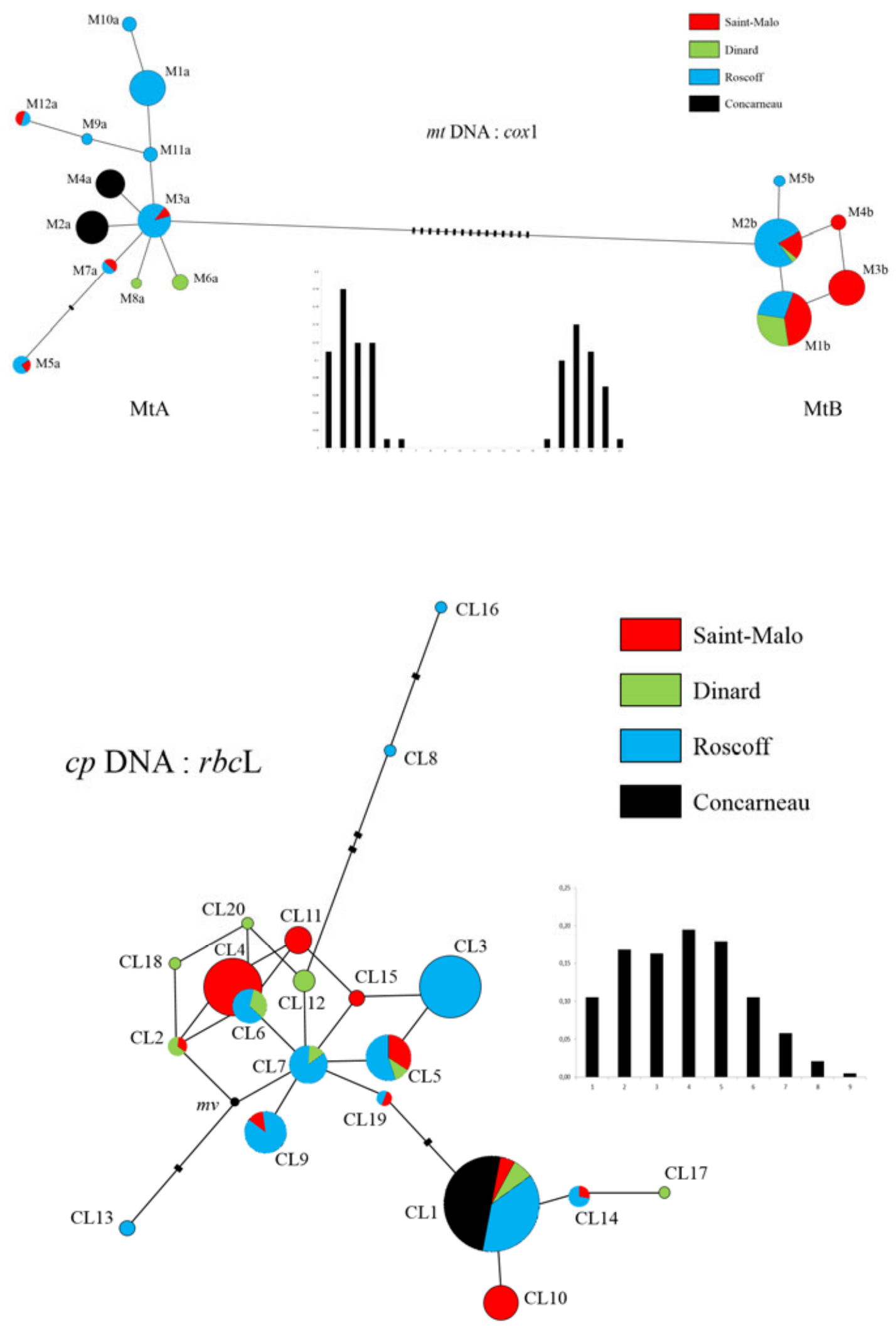

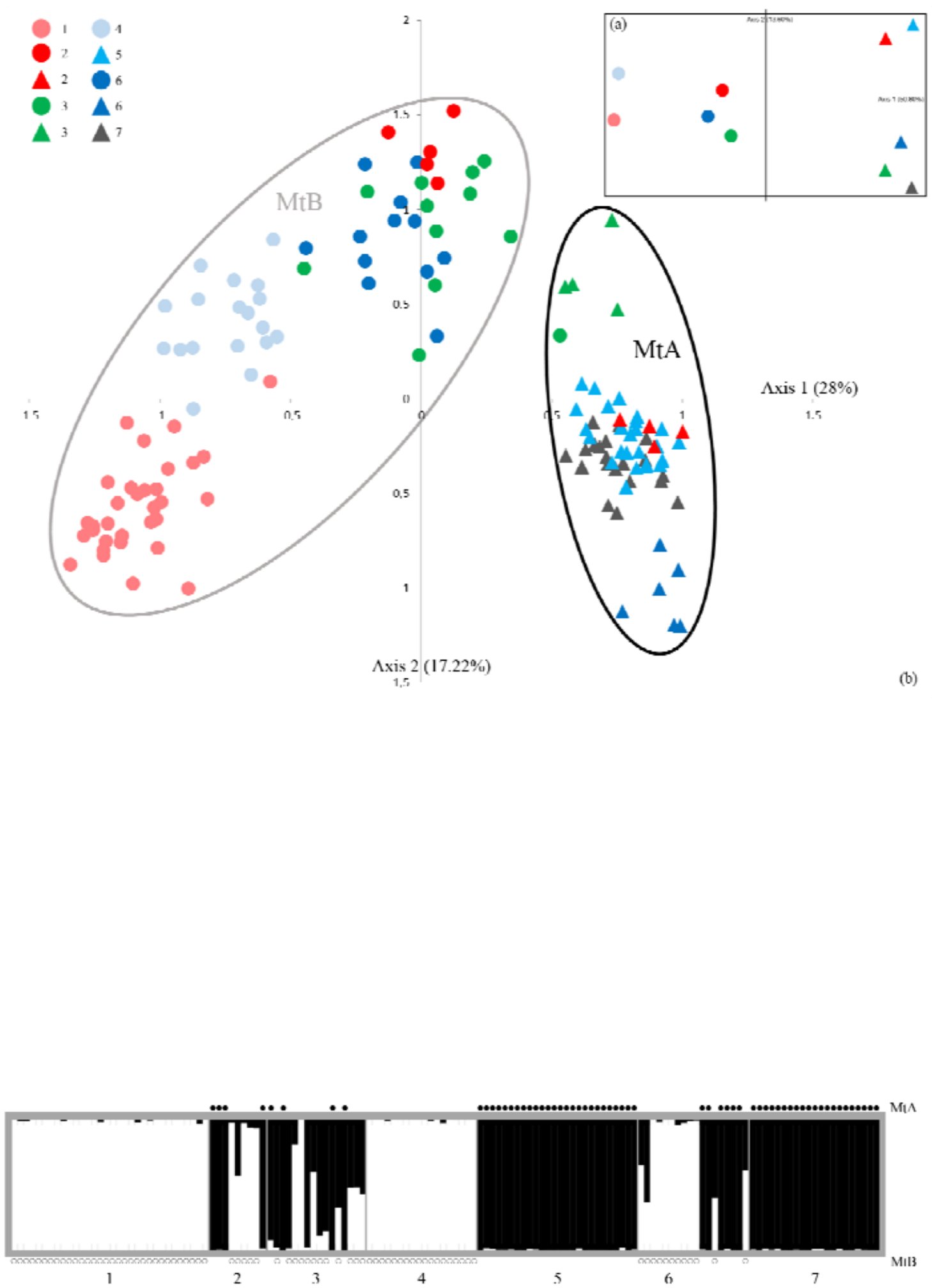